\title{
La mujer en el corrido revolucionario
}

\section{Arturo Moncada}

No hay movimiento político con mayor influencia en la música mexicana como la Revolución mexicana. Si bien la imagen de la mujer en el periodo de la Revolución mexicana es actualmente minimizado, ésta tenía una participación activa en dicho movimiento social. La Revolución inspiró a varios compositores para escribir distintos corridos utilizando la imagen de la mujer como un personaje activo en la Revolución en lugar de un personaje pasivo. Corridos tales como "El barzón" de Miguel Muñiz, "Yo me muero donde quiera" de Federico Ruiz y "Caritina" de Víctor Cordero Aurrecoechea muestran un rol activo de la mujer durante la Revolución, y aun con personajes ficticios evidencian el arduo trabajo de aquellas que estaban dispuestas a pelear por la justicia social.

"El barzón" de Miguel Muñiz es una canción de protesta que habla de un campesino que trabaja para un hacendado. Este le fía en su tienda de raya y le cobra de manera injusta a pesar de que trabaja arduamente. Aunque al principio del corrido la voz masculina es la que narra la anécdota, la voz de la mujer aparece después de la mitad del corrido preguntándole al marido acerca de los ingresos y reprochando las carencias por las que pasan por las injusticias de la tienda de raya. El punto climático del corrido es cuando, casi al terminar, la mujer alienta a su marido a revelarse contra el hacendado, a llevarlo al "salón de sesiones", no hacer caso del cura y menciona: “¡viva la Revolución! ¡muera el supremo gobierno!” Este corrido contrasta la imagen típica de la mujer sumisa que no opina en su casa, y que sólo hace lo que el marido machista le dice. En el corrido "El barzón" la mujer toma un rol activo protestando las injusticias de la tienda de raya y el poder de los ricos sobre los campesinos.

El corrido "Yo me muero donde quiera" de Federico Ruiz expone una mujer más audaz, luchadora y dispuesta a entregar la vida por su patria. Este corrido es totalmente cantado por una voz femenina quien dice: "Si me echan un lazo, respondo a balazos; si me echan un grito, de en medio los quito. Allá en las trincheras, Allá donde quieran, me muero de veras por mi pabellón". La imagen de la mujer como soldadera es rígida y bélica; en este corrido es notable que la mujer porta una carabina ya que está dispuesta a responder a balazos. Está dispuesta a confrontar a quien le levante la voz y a morir por su patria. La imagen de la mujer soldadera es reforzada en este corrido, ya que muestra que la mujer es tan audaz y guerrera como cualquier hombre.

El corrido "Caritina" de Víctor Cordero Aurrecoechea describe a una mujer audaz que por su bravura 
llegó a ser coronela pero después de los pelear murió en la desgracia, el corrido comienza resumiendo su vida: "La pobre de Caritina que anduvo en la pelotera peleando con Pancho Villa y que llegó a coronela, fue guerrillera de veras, pero murió en la miseria, brava revolucionaria, pero murió en borrachera". Con este corrido se evidencia que las soldaderas eran mujeres bravas, y llegaban a ascender a rangos como los de los hombres; es decir, si llegaban a ser coronelas, se demuestra que tenían carácter y bravura para luchar, y además tenían súbditos. Las soldaderas tales como "Caritina" eran mujeres con gran audacia para pelear en las batallas, y para enfrentarse en la Revolución. El corrido también menciona que: "La pobre de Caritina de tan valientes enaguas, gritaba "ique viva Villa!" frente al cuartel de Chihuahua..." Sin ningún temor, la mujer soldadera peleó en la Revolución, ascendió a rango de coronela y expuso su vida.

Sin duda alguna, la imagen de la mujer revolucionaria contada por los corridos que surgieron a partir de la Revolución mexicana contrasta con el clásico corrido "Adelita", el cual expone a un hombre machista que está dispuesto a todo por ella para solamente comprarle "un vestido de seda para llevarla a bailar al cuartel". En la narración de este corrido, la mujer no tienen ninguna participación activa en la Revolución, sino que solamente se ve como un objeto que acompaña al hombre revolucionario en la guerra.

Como conclusión, la Revolución mexicana influyó la música mexicana de una manera excepcional. Algunos corridos muestran a la mujer como un agente activo en la lucha. En el corrido "El barzón" la mujer toma un rol activo protestando las injusticias de la tienda de raya y el poder de los ricos sobre los campesinos. La imagen de la mujer soldadera es reforzada en el corrido "Yo me muero donde quiera", ya que muestra que la mujer es tan audaz y guerrera como cualquier hombre. De acuerdo con "Caritina", sin ningún temor la mujer soldadera peleó en la Revolución, ascendió a rangos de coronela y expuso su vida. La participación activa de la mujer fue una parte vital de la Revolución, los corridos revolucionarios evidencian su participación en esta lucha social. 


\section{Bibliografía}

Beltrán, Lola. "Yo me muero donde quiera". jAy Jalisco, no te rajes! Peerless, 2002. MP3 file.

La milpa de México. "La Caritina”. El corrido en la Revolución mexicana. Tempus, 2012. MP3 file.

Ochoa, Amparo. "E1 barzón”. Cancionero popular. Fonarte Latino, 1984. MP3 file. 